\title{
A pre-induction sporulation gene from Aspergillus nidulans
}

\author{
Craig Lewisł and Sewell P. Champe
}

Author for correspondence: Sewell P. Champe. Tel: +1908 445 2902. Fax: +1 9084455735.

Waksman Institute and Department of Molecular Biology and Biochemistry, Rutgers University, Piscataway, New Jersey 08854, USA

\begin{abstract}
Asexual sporulation in Aspergillus nidulans is an inducible developmental process controlled by genes that act before and after the inductive stimulus is applied. Genes that act before induction (pre-induction genes) potentially represent functions required for response to induction. This report describes the isolation and characterization of the acoB pre-induction gene which was cloned by complementation of a thermosensitive aconidial mutant followed by gene rescue. Genetic analysis and gene disruption confirmed the identity of the cloned gene. The mRNA of the acoB gene was present in uninduced vegetative hyphae, induced conidiating cultures and in both conidiospores and ascospores. An ORF in the nucleotide sequence of the acoB CDNA specifies a 327-residue protein unrelated to any known peptide sequence. Sequence analysis of the thermosensitive mutant allele, acoB202, revealed that the mutant phenotype is due to a frame-shift mutation that severely truncates the putative ACOB protein. Disruption of the acoB gene also produced a strain that was thermosensitive for conidiation. These properties suggest that acoB may be a gene that is required for sporulation only at elevated temperatures. Hybridization of acoB DNA with DNA from a variety of Aspergillus species showed that homology to this gene is largely restricted to sexually sporulating species that belong to the nidulans group.
\end{abstract}

Keywords: Aspergillus nidulans, sporulation gene, species homology, thermosensitive mutant.

\section{INTRODUCTION}

Cellular differentiation in the homothallic filamentous fungus Aspergillus nidulans occurs in a highly ordered fashion. Germination of a dormant spore gives rise to a network of branched hyphal filaments which comprise the young vegetative colony. At a precisely determined time after germination the colony begins to produce asexual spores (conidia) by mitosis at the swollen tips of specialized aerial hyphae (conidiophores). Asexual sporulation is followed by the appearance of sexual fruiting bodies (cleistothecia), which are small $(200 \mu \mathrm{m})$ spherical shells inside which sexual spores are generated by meiosis. Cleistothecia can number several thousand per $\mathrm{cm}^{2}$ giving the central (oldest) zone of mature colonies a pulvinate appearance. At $37^{\circ} \mathrm{C}$ asexual sporulation begins at $20 \mathrm{~h}$ and sexual sporulation at $50 \mathrm{~h}$ post-inoculation (Champe et al., 1987). This developmental sequence occurs for

†Present address: Enzon Inc., Piscataway, NJ 08854, USA

The GenBank accession number for the sequence reported in this paper is U18265. colonies growing at an air interface, e.g. an agar surface. When grown in a submerged state, colonies remain undifferentiated indefinitely; no spores, either asexual or sexual, nor spore-bearing structures are formed. For such colonies sporulation can be initiated at will by transferring the mycelium to an agar surface, an operation referred to as induction (Axelrod et al., 1973). Timberlake (1980) showed that induction results in the appearance of many new mRNA species.

The genetic control of these developmental events has been studied by both classical and molecular methods (reviewed by Timberlake, 1990). Temperature-shift experiments with thermosensitive aconidial mutants were used to determine at what time or under what conditions a mutant becomes insensitive to the temperature that blocks conidiation. These studies revealed two general classes of sporulation mutants - pre-induction mutants and post-induction mutants (Yager et al., 1982). A pre-induction mutant was defined as one that becomes temperatureinsensitive while growing in the uninduced state. In contrast, a post-induction mutant becomes temperatureinsensitive only after the mycelium has been induced. 
Experimentally, the two classes can be distinguished by a qualitative test in which, after a period of vegetative growth at the permissive temperature, mutant colonies are induced and simultaneously shifted to the restrictive temperature. In such an experiment, a pre-induction mutant will form conidia whereas a post-induction mutant will not. It was suggested that pre-induction genes may prepare the mycelium to respond to induction, i.e. to become developmentally competent (Axelrod et al., 1973), whereas post-induction genes may act directly in the formation of spores.

Three pre-induction genes $(a c o A, a c o B$ and $a c o C)$ have been identified by temperature-shift experiments with thermosensitive mutants (Butnick et al., 1984b), but heretofore none have been characterized at the molecular level. Mutants of these genes are completely asporogenous at the restrictive temperature making neither asexual nor sexual spores nor spore-bearing structures. Mutants of all three genes also exhibit a uniform metabolic aberration not observed for other sporulation mutants: pre-induction mutants overproduce by about 100 -fold a set of secondary metabolites, the major components of which have been identified as diphenyl ethers, for example diorcinol (Butnick et al., 1984a). To obtain some further clue to the function of pre-induction genes and their role in sporulation we have cloned and partially characterized the $a c o B$ gene as described in this paper.

\section{METHODS}

Fungal strains and plasmids. Genotypes of Aspergillus nidulans strains are described in the text. Strains designated with a WIM prefix were constructed in this laboratory. Other Aspergillus strains and species were acquired from the Fungal Genetics Stock Center (University of Kansas) or the American Type Culture Collection (Rockville, MD, USA). Plasmid pRG3 was a gift from Dr N. R. Morris and the $\lambda$-Zap cDNA library from $\mathrm{Dr}$ W. E. Timberlake.

Aspergillus growth and genetic manipulations. Aspergillus species were grown in YGT complete medium as previously described (Kurtz \& Champe, 1981). Uridine auxotrophs were grown on YGT medium supplemented with $20 \mathrm{mM}$ uridine. Conidia from acoB202 and acoC193 strains were harvested from 40-h-old YGT agar plates containing $1 \mathrm{M}$ sucrose which was added to promote conidiation. Genetic crosses were done by standard methods (Pontecorvo et al., 1953).

Nucleic acid isolation. Aspergillus genomic DNA was extracted from powdered lyophilized mycelium $\left(40 \mathrm{mg} \mathrm{ml}^{-1}\right)$ with lysis buffer $(50 \mathrm{mM}$ Tris $/ \mathrm{HCl}, \mathrm{pH} 8 \cdot 0,100 \mathrm{mM}$ EDTA, $2 \%$,w/v, sarkosyl, $25 \mu \mathrm{g}$ RNase $\mathrm{A} \mathrm{ml}^{-1}$ ) by incubation for $45 \mathrm{~min}$ at $65^{\circ} \mathrm{C}$. After cooling, proteinase $\mathrm{K}$ was added to a final concentration of $100 \mu \mathrm{g} \mathrm{ml}^{-1}$ and the mixture was incubated for at least $5 \mathrm{~h}$ at $42^{\circ} \mathrm{C}$. After removal of debris by low speed centrifugation, genomic DNA was banded in a CsCl $\left(0.9 \mathrm{~g} \mathrm{~m}^{-1}\right)$ gradient (containing $25 \mu \mathrm{g}$ ethidium bromide $\mathrm{ml}^{-1}$ ) at $210000 \mathrm{~g}$ for $48 \mathrm{~h}$. The DNA was extracted with butanol and diluted with 2 vols water prior to precipitation with 2 vols ethanol.

For small scale $(1.5 \mathrm{ml})$ genomic DNA isolations, cleared lysates were extracted once with phenol, once with phenol/chloroform $(1: 1, \mathrm{v} / \mathrm{v})$, once with chloroform and then precipitated with 0.5 vols PEG $(20 \%$, w/v, PEG $6000,2 \cdot 5 \mathrm{M} \mathrm{NaCl})$ for $3 \mathrm{~h}$ on ice. DNA pellets were dissolved in TE buffer $(10 \mathrm{mM}$ Tris $/ \mathrm{HCl}$,
$1 \mathrm{mM}$ EDTA, pH 8.0), reprecipitated with ethanol and dissolved in $50 \mu \mathrm{l}$ TE.

Total RNA was isolated from hyphae, conidiating cultures and spores by established methods (Timberlake, 1986; Jurgenson \& Champe, 1990).

Construction of a plasmid genomic library. Aspergillus DNA from the prototrophic wild-type strain FGSC\#4 was partially digested with Sau3A and fragments in the size range of 4-7 kb were purified by gel electrophoresis. This DNA was ligated into the BamHI site of the pUC19-derived Aspergillus shuttle vector pRG3 (Waring et al., 1989). Plasmid pRG3 contains the uridineselectable pyr4 gene of Neurospora crassa, which is capable of complementing the $A$. nidulans pyr $G 89$ mutation (Ballance et al., 1983). After transformation of Escherichia coli JM83, approximately 45000 recombinants were pooled to form the library and used to purify DNA for Aspergillus transformations.

Aspergillus transformation. $A$. nidulans protoplasts were prepared and transformed as described by Ballance $e t$ al. (1983) with some modification (May et al., 1985). Fifty millilitres of complete medium was inoculated with $10^{9}$ conidia and grown for $6 \mathrm{~h}$ at $33^{\circ} \mathrm{C}$. Germlings were collected by low speed centrifugation and resuspended in $40 \mathrm{ml}$ freshly made sterile protoplasting solution $\left[0.4 \mathrm{M}\left(\mathrm{NH}_{4}\right)_{2} \mathrm{SO}_{4}, 50 \mathrm{mM}\right.$ citric acid, $\mathrm{pH} 6.0,0.5 \%$ yeast extract, $1 \%$, w/v, sucrose, $12.5 \mathrm{mM} \mathrm{MgSO}_{4}, 2.5 \mathrm{mg} \mathrm{BSA}$ $\mathrm{ml}^{-1}, 5 \mathrm{mg}$ NovoZym $234 \mathrm{ml}^{-1}$ (Novo Biolabs), $2 \cdot 5 \mu$ l glusulase $\mathrm{ml}^{-1}$ (Du Pont)]. The suspension was incubated at $33^{\circ} \mathrm{C}$ with gentle agitation for $2.5 \mathrm{~h}$. Protoplasts were filtered through Miracloth, collected by centrifugation, washed twice with icecold protoplast washing solution $\left[0.4 \mathrm{M}\left(\mathrm{NH}_{4}\right)_{2} \mathrm{SO}_{4}, 50 \mathrm{mM}\right.$ citric acid, $\mathrm{pH} 6.0,1 \%$ sucrose] and resuspended in $1 \mathrm{ml}$ icecold $10 \mathrm{mM}$ MES buffer, $\mathrm{pH} 6.0$, containing $0.6 \mathrm{M} \mathrm{KCl}$ and $50 \mathrm{mM} \mathrm{CaCl}{ }_{2}$. Transforming DNA (10-40 $\mu \mathrm{g}$ in $\left.10 \mu \mathrm{l} \mathrm{TE}\right)$ was added to $100 \mu \mathrm{l}$ of competent protoplasts followed by $50 \mu \mathrm{l}$ $25 \%$ PEG 6000, containing 0.1 $\mathrm{M} \mathrm{CaCl}_{2}, 0.6 \mathrm{M} \mathrm{KCl}, 10 \mathrm{mM}$ Tris $/ \mathrm{HCl}, \mathrm{pH} 7 \cdot 5$, and held on ice for $20 \mathrm{~min}$. The mixture was diluted by addition of $1 \mathrm{ml}$ of the PEG solution and incubated for an additional $20 \mathrm{~min}$ at room temperature. Aliquots of transformation reactions were added to $3 \mathrm{ml}$ molten $\left(46^{\circ} \mathrm{C}\right)$ regeneration medium $(0.5 \%$ yeast extract, $1 \mathrm{M}$ sucrose, $10 \mathrm{mM}$ $\mathrm{MgSO}_{4}, 0 \cdot 1 \%$ trace elements, $0 \cdot 1 \%$ glucosamine, $1 \%$, w/v, agar) and poured into empty Petri plates. Plates were incubated at $37^{\circ} \mathrm{C}$ for $20 \mathrm{~h}$ and overlaid with $20 \mathrm{ml}$ of molten, nonosmotic, selective medium. Cultures were incubated at $42{ }^{\circ} \mathrm{C}$ until mature colonies developed. Thermosensitive pre-induction mutants growing at $42^{\circ} \mathrm{C}$ on medium containing $1 \mathrm{M}$ sucrose sporulate well; this overlay method eliminated the need for replica plating onto non-osmotic media.

Plaque, colony and filter hybridization. A $\lambda$-Zap cDNA $A$. nidulans library (Dean \& Timberlake, 1989) was screened with acoB transforming DNA on Duralon-UV nylon membranes (Stratagene) and UV cross-linked as described by the manufacturer. Bacterial colonies from the plasmid genomic library described above were also screened by hybridization on Duralon. Southern and Northern hybridizations were performed on Nytran membranes (Schleicher \& Schuell). Standard hybridizations were done at $42{ }^{\circ} \mathrm{C}$ in $50 \%(\mathrm{v} / \mathrm{v})$ formamide, $5.3 \times$ SSC, $5 \times$ Denhardt's solution, $0.5 \%$ SDS, $0.2 \mathrm{mg}$ boiled salmon sperm DNA ml-1. Filters were washed at $68^{\circ} \mathrm{C}$ in $0.1 \times$ SSC containing $0.5 \%$ SDS. For low stringency hybridization, $25 \%$ formamide was used and incubation was at $28^{\circ} \mathrm{C}$. Low stringency washes were done for $30 \mathrm{~min}$ at $42{ }^{\circ} \mathrm{C}$ in $1 \times$ SSC containing $0.5 \%$ SDS.

Deletion subclones, sequencing and PCR. Sets of $a c 0 B$ nested deletion subclones for DNA sequencing were made with the Erase-a-Base System (Promega). Plasmid DNA from the 
deletion subclones was sequenced by the dideoxy chaintermination method using the Sequenase Version 2.0 sequencing kit (USB). DNAs were sequenced from both strands using the universal and reverse primers and analysed with the GCG software on a VAX computer.

PCR was done with the GeneAmp kit (Perkin Elmer Cetus) in a Biosycler oven (BIOS) using parameters recommended by the manufacturers. The template for PCR was $100 \mathrm{ng}$ of acoB202 genomic DNA. An EcoRI site was added to the $5^{\prime}$ primer (CTC GAA TTC CTT GCA CAT TCA ACC TGC AAC) and a $B a m H I$ site was added to the $3^{\prime}$ primer (ACA GGA TCC AGG CGT T'TG CTG GTA GTC TTG CC). The PCR product was cloned into pBluescript and sequenced as described above.

\section{RESULTS AND DISCUSSION}

\section{Cloning of the acoB pre-induction gene}

The $a c 0 B$ gene was isolated by the method used by Osmani et al. (1987) for cloning the $A$. nidulans nim $A$ gene. The strategy is to correct the mutant defect by transformation with wild-type DNA and then to recover the transforming DNA from the transformant. The uridine-requiring strain WIM-268 (acoB202 pyrG89) was transformed to uridine independence by a plasmid genomic $A$. nidulans library using the $N$. crassa pyr4 gene as a selectable marker (see Methods). From 22000 uridine prototrophs, 11 transformants stably conidiated at the restrictive temperature,

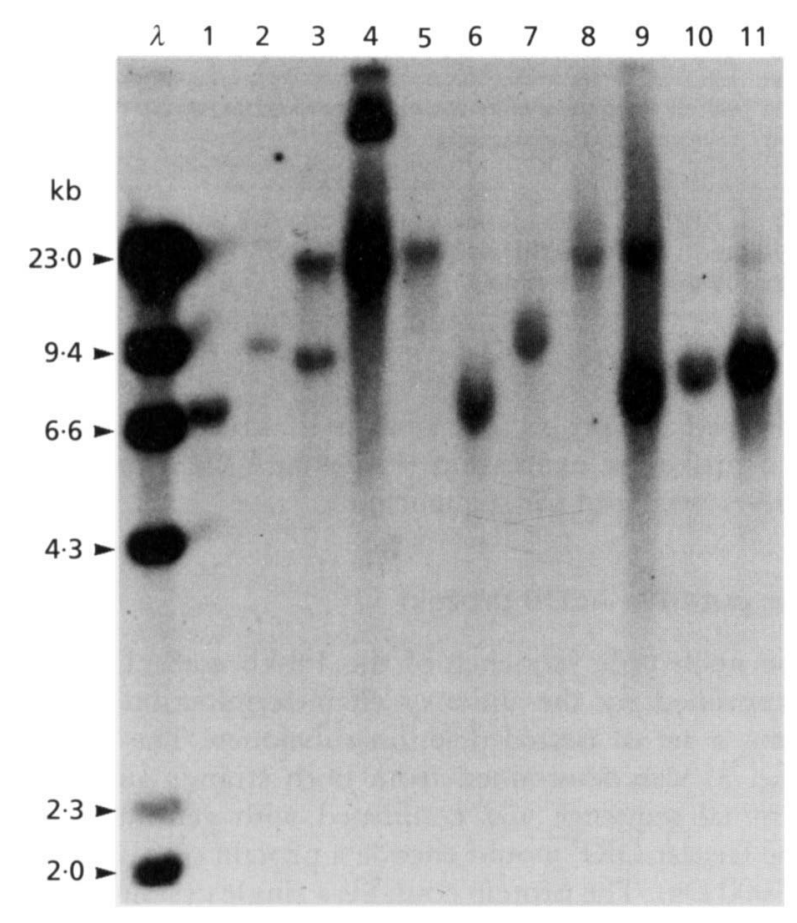

Fig. 1. Southern analysis of genomic DNA isolated from 11 conidial transformants (TRA-1 to -11) of the aconidial mutant acoB202. Samples of the DNA were digested with Bg/ll and hybridized with radiolabelled pUC DNA (to which labelled $\lambda$ DNA was added to visualize the $\lambda$ markers). Transformants TRA1, -6 and -10 represent apparent single integration events. Transformants TRA-4 and -9 represent multiple tandem integrations.
$42{ }^{\circ} \mathrm{C}$. Of the 11 transformants, three (TRA-1, -6 and -10 ) differentiated in a manner indistinguishable from the wild type, while the other eight showed some differences in either conidiation, sexual sporulation or both. Southern analysis of each transformant was performed on genomic DNA digested with $B g / I$ and probed with pUC19. Because the plasmid component of the transformation vector is not cut by $B g / \mathrm{II}$, each band on the autoradiograph (Fig. 1) is indicative of a single integration event. Bands of high molecular mass or of exceptionally strong intensity presumably arose from multiple tandem integrations. It is seen that the transformants that were indistinguishable from the wild type each resulted from a single integration event, whereas the transformants that differed in sporulation behaviour from wild type resulted from multiple integrations.

To identify a transformant that resulted from an integration at the $a c o B$ locus, a two-step gene replacement was performed as described by Miller et al. (1985). Transformant TRA-1 was selected as a likely candidate for a single acoB-specific integration and transformant TRA-3, which contains two copies of the plasmid vector, was used as a negative control. If the integration is a sitespecific homologous event, a chromosomal arrangement will be generated in which plasmid DNA is flanked by the mutant $a c o B$ gene on one side and the wild-type gene on the other. During meiosis, plasmid DNA, including the selectable marker and one copy of the duplicated gene, can be excised by recombination. The two transformants were thus self-crossed, ascospores collected and plated, and colonies were scored for uridine dependence by replica plating. For TRA-1, $1 \%$ of the colonies were URI $^{-}$which agrees with excision frequencies from previous studies (Miller et al., 1985). By contrast, 10\% of the colonies from the TRA-3 multiple integrant were $\mathrm{URI}^{-}$, indicating that a heterologous integrant excises at a higher frequency.

To demonstrate that the $\mathrm{ACO}^{+}$transforming DNA had replaced the resident $a c o B$ gene, an $\mathrm{ACO}^{+} \mathrm{URI}^{-}$excision strain, obtained from a self cross, was crossed with a wildtype strain and aconidial segregants were scored. If an integration occurred into another chromosome or distant from the $a c o B$ locus, $50 \%$ of the progeny would be expected to be aconidial. If the $\mathrm{ACO}^{+}$transforming DNA integrated into the $a c o B$ locus and the mutant allele was excised during meiosis, then all progeny would be conidial. Of 300 progeny resulting from such a cross with the TRA-1 excision strain, no aconidial progeny were seen. In contrast, using the TRA-3 excision strain 13 out of 25 progeny were aconidial. These results strongly support the conclusion that the transformant TRA-1 arose from a single site-specific integration at the $a c o B$ locus. TRA-1 was thus used to recover the $a c o B$ transforming DNA.

\section{Isolation of acoB genomic and CDNA}

The acoB transforming DNA in TRA-1 should be adjacent to the pRG3 bacterial vector. If the vector and flanking DNA were excised from the genome by partial restriction 

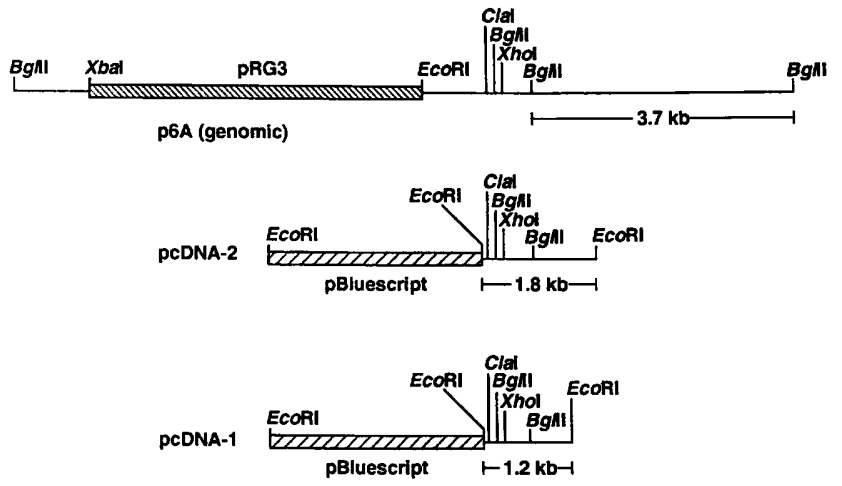

Fig. 2. Relationship of the $a c o B$ genomic plasmid $p 6 A$ to two transforming CDNA clones (pCDNA-2 and -1). The larger CDNA plasmid was sequenced and the smaller plasmid was used as an acoB-specific hybridization probe. An ECoRI site at the $5^{\prime}$ end was derived from the cloning vector.

digestion, some of the excised fragments should include the acoB complementing DNA. All such fragments should be recoverable in $E$. coli as a plasmid because pRG3 contains the ampicillin resistance gene and a bacterial origin of replication. Following this rationale, DNA from TRA-1 was partially digested with $B g / I \mathrm{I}$ (which does not cut pRG3), ligated in dilute solution to favour the formation of unimolecular circles and used to transform E. coli DH10B to ampicillin resistance $\left(\mathrm{Ap}^{\mathbf{R}}\right)$. Plasmid DNA was isolated from several of the $A \mathrm{p}^{\mathrm{R}}$ isolates and each was characterized physically and functionally. Each plasmid was able to transform an $a c o B$ pyr $G$ recipient to uridine independence, but only the largest plasmids could correct the aconidial phenotype. This analysis identified a $3.7 \mathrm{~kb} \mathrm{Bg} / \mathrm{II}$ fragment, from a plasmid designated p6A, that complemented the acoB202 lesion. Attempts to identify a smaller complementing fragment, either by subcloning restriction fragments or direct fragment transformation (Timberlake et al., 1985), were unsuccessful.

The $3.7 \mathrm{~kb}$ transforming fragment hybridized to three transcripts $(0.8,1.8$ and $4.0 \mathrm{~kb})$ in a Northern blot of undifferentiated hyphal RNA. This $3.7 \mathrm{~kb}$ fragment apparently contains, in addition to the $a c o B$ gene, sequences from other genes. To obtain an acoB-specific probe, a cDNA library (Dean \& Timberlake, 1989) was probed with the $3.7 \mathrm{~kb}$ transforming $B g / \mathrm{II}$ fragment. Two independent $\mathrm{CDNA}$ clones were isolated upon screening $5 \times 10^{5}$ plaques. These clones, pcDNA-1 and pcDNA-2 contained Aspergillus cDNA of 1.2 and $1.8 \mathrm{~kb}$, respectively. Fig. 2 shows partial restriction maps of these two clones and their relation to $\mathrm{p} 6 \mathrm{~A}$ and the $3.7 \mathrm{~kb}$ genomic fragment (the fragment bounded by the two right-most $B g l$ II sites). In transformations both of these cDNAs corrected all phenotypes of the acoB mutant. When used as probes in Northern analyses, the $1.2 \mathrm{~kb}$ cDNA hybridized to a single $1.8 \mathrm{~kb}$ transcript and the $1.8 \mathrm{~kb}$ cDNA hybridized to two transcripts, one 0.8 and the other $1.8 \mathrm{~kb}$. These transcripts matched two of the three mRNAs seen when the $3.7 \mathrm{~kb} B g / \mathrm{II}$ genomic fragment

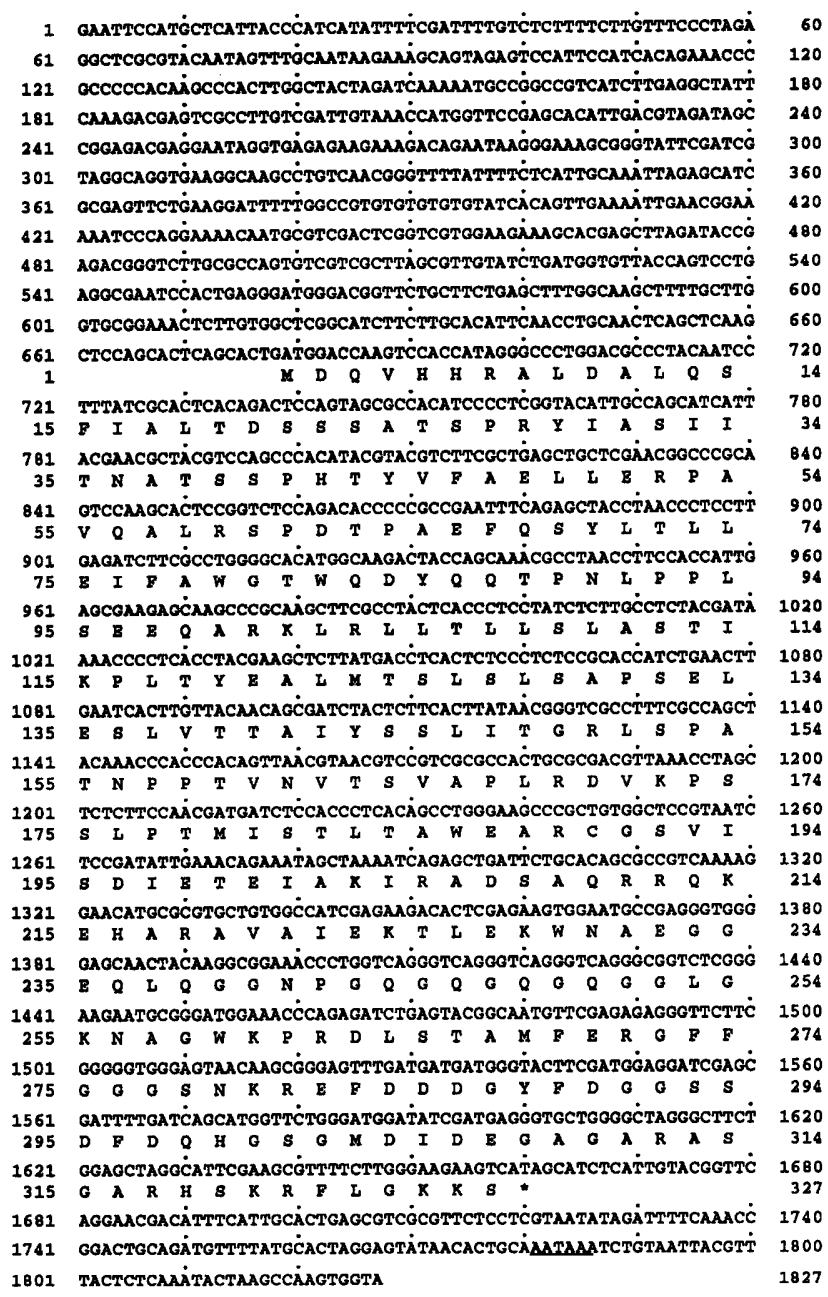

Fig. 3. Nucleotide sequence of aCOB CDNA-2 and corresponding predicted amino acid sequence. A typical polyadenylation signal is shown underlined.

was used as a probe. The smaller $1.2 \mathrm{~kb}$ cDNA was used as a probe for expression studies and the larger $1.8 \mathrm{~kb}$ cDNA was used for sequencing.

\section{The putative ACOB protein}

The nucleotide sequence of the $1.8 \mathrm{~kb}$ acoB $\mathrm{cDNA}$ was determined by the dideoxy chain-termination method, using a set of nested deletion subclones. The sequence (Fig. 3) was determined from both strands and the 3'terminal sequence was confirmed with genomic DNA. The largest ORF would encode a protein of 327 residues $(35000 \mathrm{Da})$. The protein contains a single cysteine residue and a glycine-glutamine repeat (...GQGQGQGQG ...) from position 234 to 250 . Comparison of the deduced ACOB amino acid sequence with the GenPept, SwissProt and PIR protein databases failed to identify matches or functional motifs, although there are a number of potential phosphorylation sites and two potential sites for $\mathrm{N}$-linked glycosylation (residues 36 and 161). When checked against the GenBank and EMBL DNA databases, 


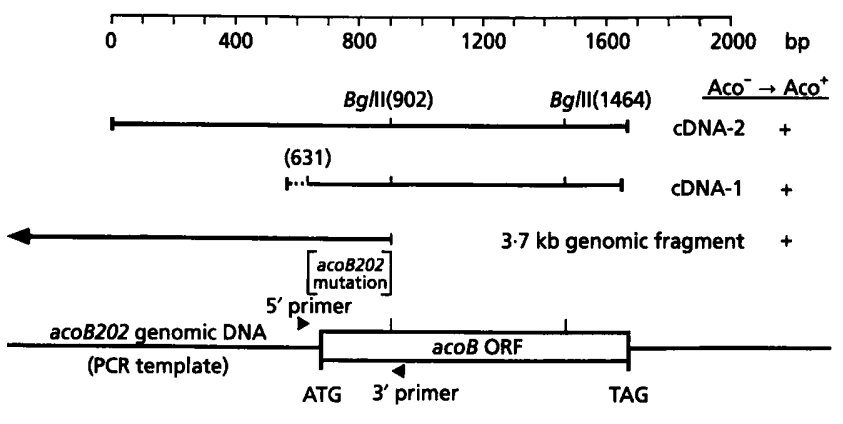

Fig. 4. Localization of the genetic lesion of acoB202. PCR primers were designed to flank a 269 bp region overlapped by the three transforming clones. Restriction sites were added to the ends of the primers to facilitate cloning (see Methods). The dashed segment of CDNA-1 represents DNA sequence that differs from CDNA-2.

the nucleotide sequence of the $a c o B$ gene showed no significant matches with known sequences. The $a c o B$ gene appears to encode a novel protein unrelated to any known peptide sequence.

The $a c o B$ cDNA-2 sequence contains a 678 nucleotide untranslated $5^{\prime}$ leader and the $3^{\prime}$ end, sequenced from genomic DNA, has a typical polyadenylation signal (AATAAA) 120 bases downstream from the stop codon. Although this $5^{\prime}$ leader is long, leaders of several hundred bases are not unprecedented in $A$. nidulans (Timberlake, 1990). The leader sequence shown in Fig. 3 was derived from a single cDNA clone; transcriptional mapping will be required to precisely define the end of the $a c 0 B$ message. Such analysis might prove interesting in light of the finding of Prade \& Timberlake (1993) that the $\operatorname{brl} A$ conidiation gene of $A$. nidulans has two overlapping transcription units, one of which initiates in an intronic sequence of the other.

\section{Identification of the mutation in acoB202}

From the results of transformation experiments using genomic and cDNA it was possible to localize the acoB202 mutation to a sequence of about 300 bases. Both acoB cDNAs transform acoB202 to wild type and their sequences are identical downstream of nucleotide 631 of the $1.8 \mathrm{~kb}$ cDNA. Thus, the mutation is $3^{\prime}$ of base 631 . The transforming $3.7 \mathrm{~kb} B g / \mathrm{II}$ genomic fragment corresponds to DNA upstream of the $B g / \mathrm{II}$ site at position 902 of the $1.8 \mathrm{~kb} \mathrm{cDNA}$ sequence. Therefore, the genetic lesion must lie in the $269 \mathrm{bp}$ stretch between nucleotides 631 and 902 (Fig. 4).

PCR primers were made that flanked the $269 \mathrm{bp}$ region and used to generate a 335 bp product from WIM-146 (acoB202) template DNA. The fragment was subcloned into pBluescript and sequenced. To avoid errors introduced by the PCR reaction, DNA was prepared from a pool of about 100 recombinant clones. In addition, the PCR reaction, subcloning and sequencing were done in triplicate, just in case a base misincorporation occurred in

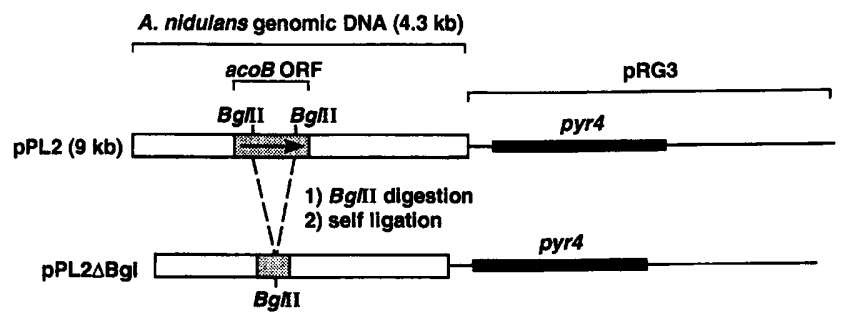

Fig. 5. Construction of the deletion plasmid pPL2 $\triangle$ Bgl. Plasmid PPL2, isolated from the plasmid genomic library (see Methods), contained $4.3 \mathrm{~kb}$ of $A$. nidulans (strain FGSC\#4) genomic DNA cloned into pRG3. Plasmid pPL2 was digested with Bg/ll and circularized to produce pPL2 $\triangle \mathrm{Bgl}$, which contained a $562 \mathrm{bp}$ deletion in the middle of the $a C O B$ coding region. The Bg/ll sites of PPL2 are the same as those shown for PCDNA-1 and PCDNA-2 in Fig. 2.

an early round of amplification. The 335 bp product was sequenced from both strands and compared to the wildtype $a c o B$ sequence. A single CG bp at position 782 was absent from the acoB202 allele. This deletion results in out-of-frame translation of codons $35-70$ and the occurrence, at codon 71 , of a TAA termination signal. Thus, the acoB202 mutant produces a grossly truncated ACOB gene product containing only the $\mathrm{N}$-terminal $10 \%$ of the sequence.

\section{Disruption of the wild-type acoB locus}

Thermosensitivity of a mutant is usually attributed to a missense mutation that changes the thermostability of the gene's protein product. It is thus paradoxical that the acoB202 mutation, which produces only a small fragment of the ACOB protein, should be thermosensitive. To determine whether other massive changes in the $a c 0 B$ gene also result in a thermosensitive phenotype, the aco $B$ gene was disrupted by integrative transformation with a plasmid that contained a large deletion in the $a c o B$ gene. This deletion vector ( $\mathrm{pPL} 2 \Delta \mathrm{Bgl}$ ) was constructed from plasmid pPL2, which contains the acoB coding region and, in addition, $1.3 \mathrm{~kb}$ upstream and $2.2 \mathrm{~kb}$ downstream of the ORF. Plasmid pPL2 was digested with $B g / \mathrm{II}$, religated and used to transform $E$. coli. The resultant plasmid, pPL2 $\triangle \mathrm{Bgl}$, has 562 bases removed from the middle of the acoB coding region. This vector also contains the pyr4 gene for uridine selection (Fig. 5).

The two-step gene replacement technique was used to replace the wild-type $a c o B$ with the deletion construct. After transforming WIM-282 (yA2 pyro $A 4$ pyrG89) with pPL $2 \Delta \mathrm{Bgl}$, conidia were collected from 24 uridineindependent colonies. Each strain was allowed to selfcross and ascospores were plated at $42{ }^{\circ} \mathrm{C}$. From the fact that the frame-shift mutant acoB202 is thermosensitive, it was reasonable to expect that an $a c o B$ deletion would also be thermosensitive. Indeed, roughly half of the $\mathrm{URI}^{+}$ transformants produced $\mathrm{ACO}^{\text {ts }} \mathrm{URI}^{-}$progeny. To demonstrate that the in vitro-disrupted $a c o B$ gene replaced the resident wild-type allele, a Southern blot of $\mathrm{ACO}^{\text {ts }} \mathrm{URI}^{-}$ progeny from eight uridine prototrophs was performed 


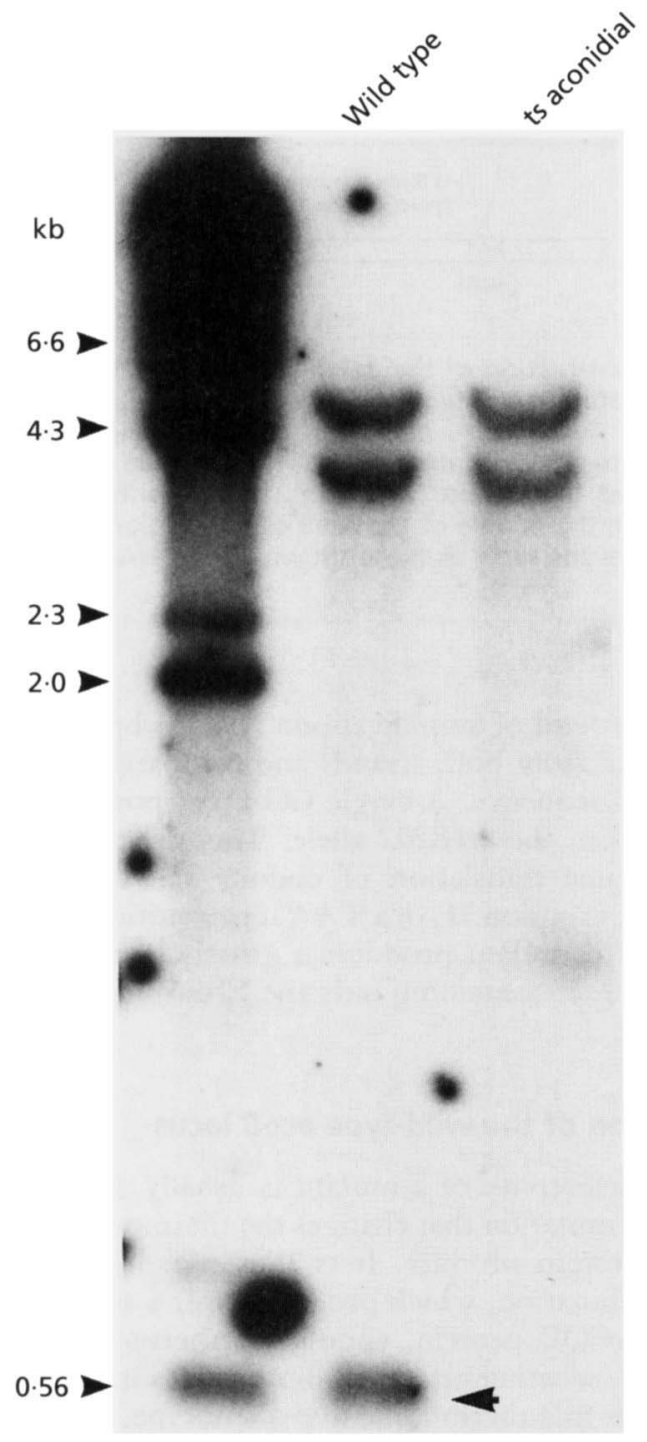

Fig. 6. Disruption of $a c o B$ by plasmid pPL2 $\triangle B$ gl. DNA from the wild-type strain WIM-282 and a representative $A^{2} O^{\text {ts }}$ URI $^{-}$ disruptant strain was digested with $B g / I I$ and probed with the $4.3 \mathrm{~kb}$ genomic insert from pPL2. The $562 \mathrm{bp}$ internal acoB Bg/ll fragment, indicated by the arrow, is present in the wild type but is absent from the disruptant.

and probed with the genomic fragment from pPL2. Untransformed WIM-282 control DNA produced the expected three bands, the $562 \mathrm{bp}$ fragment (middle of the acoB ORF) and two larger flanking fragments. The $562 \mathrm{bp}$ fragment was absent in all eight disruptants. Fig. 6 shows a Southern analysis of the wild-type control and one $\mathrm{ACO}^{\mathrm{ts}} \mathrm{URI}^{-}$representative. The disruptants were phenotypically indistinguishable from acoB202, including the lack of sexual sporulation and the thermosensitive overproduction of phenolic metabolites. It should be noted that these disruptants should be able to produce the same region of the $a c 0 B$ polypeptide as produced by the acoB202 frame-shift mutant.

The simplest explanation of the thermosensitive pheno-

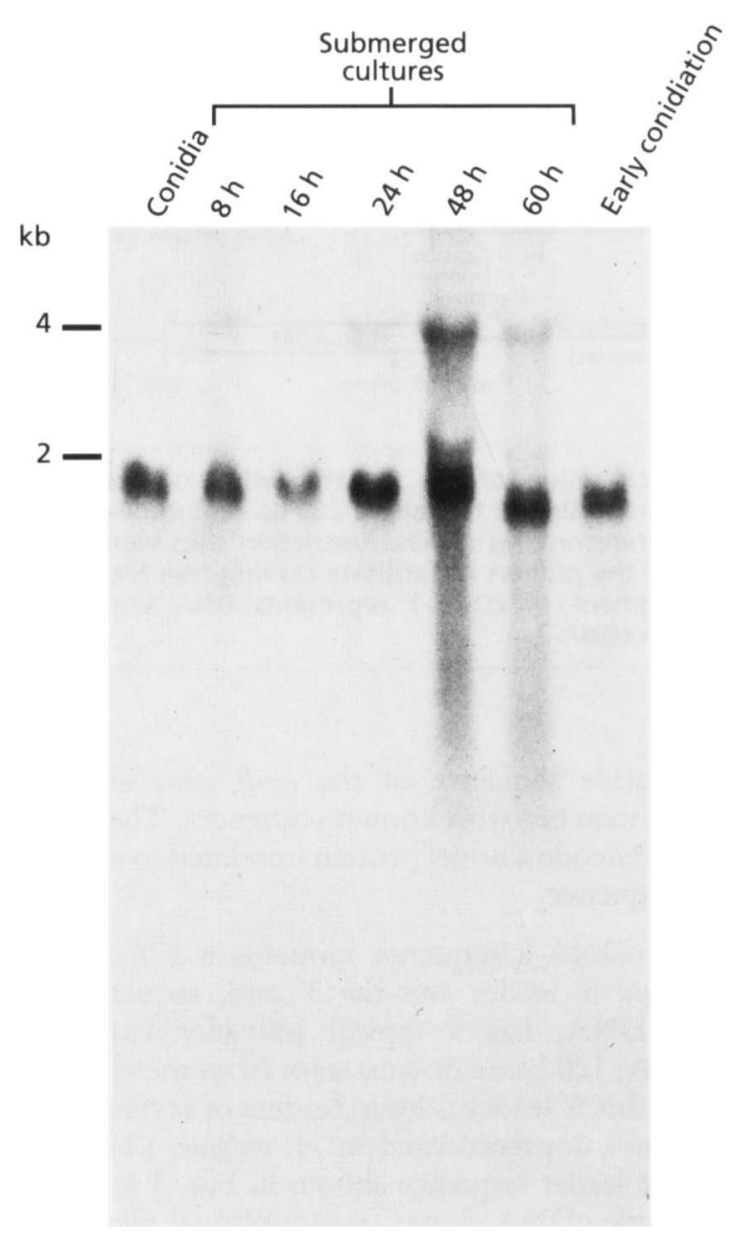

Fig. 7. Constitutive expression of the acoB gene. Total RNA was isolated from the sources indicated and probed with the acoBspecific CDNA-1. Equal amounts of RNA (about $30 \mu \mathrm{g}$ ) were applied to each lane except for the 48-h lane which was inadvertantly overloaded. The RNA in the lane labelled 'early conidiation' was from a surface-grown (induced) culture harvested after conidiophores began to form but before conidia appeared. All cultures were grown at $37^{\circ} \mathrm{C}$. The $2 \mathrm{~kb}$ and $\mathbf{4} \mathrm{kb}$ ribosomal RNA markers were located by staining with ethidium bromide (not shown).

type of $a c o B$ null mutants is that the $a c o B$ gene is required for sporulation at high temperatures but not at low temperatures. For such a gene, any mutation that destroys gene function would result in a thermosensitive phenotype. Interestingly, preliminary characterization of the aco $C$ pre-induction gene (to be published elsewhere) indicates that this gene also is required for sporulation only at elevated temperatures. This phenotype is not unprecedented. In yeast, for example, null mutants of certain genes for actin binding proteins are thermosensitive for growth (Welch et al., 1993). In this case a plausible explanation for the thermosensitive phenotype is that the binding proteins stabilize actin to temperature extremes. 
Table 1. Homology of various Aspergillus species to the acoB DNA sequence

\begin{tabular}{|llcc|}
\hline Species & Group & $\begin{array}{c}\text { Sexual } \\
\text { cycle }\end{array}$ & $\begin{array}{c}\text { acoB } \\
\text { homology }\end{array}$ \\
\hline A. nidulans & nidulans & + & + \\
A. beterotballicus & nidulans & + & + \\
A. parvathecius & nidulans & + & + \\
A. rugulosus & nidulans & + & + \\
A. violaceus & nidulans & + & + \\
A. variecolor & nidulans & + & - \\
A. silvaticus & nidulans & - & - \\
A. subsessilis & nidulans & - & - \\
A. oryzae & nidulans & - & - \\
A. awamori & niger & - & - \\
A. niger & niger & - & - \\
A. ornatus & ornatus & + & - \\
A. raperi & ornatus & - & - \\
A. funiculosus & sparsus & - & + \\
A. puniceus & ustus & - & - \\
A. sidowi & versicolor & - & - \\
\hline
\end{tabular}

\section{Transcription analysis}

Temperature-shift experiments suggest that pre-induction genes execute functions in the uninduced state shortly before conidiation (Butnick et al., 1984a; Yager et al., 1982 ). With the availability of an acoB-specific probe we were able to examine directly the stage-specific transcription of this gene. Northern analyses (Fig. 7) revealed that the acoB transcript was present in mycelium at all times of development and whether the mycelium was induced to conidiate or uninduced. The $a c o B$ transcript was also present at comparable levels in both conidia and ascospores (not shown). A similar lack of developmental regulation was found by Adams et al. (1992) for the acoD gene which, like the pre-induction genes, is required for sexual as well as asexual sporulation. Temperature-shift experiments, nevertheless, indicate unambiguously that aco $D$ is a post-induction gene. It is thus evident that the thermosensitive period of a mutant does not necessarily coincide with the period of transcription of that gene; transcription analysis and temperature-shift analysis can give complementary information about gene expression. To reconcile their findings, Adams et al. (1992) suggest that the activity of the acoD gene may be controlled posttranscriptionally.

\section{Homologues of the acoB gene in other Aspergillus species}

Most species of Aspergilli are imperfect, i.e. they do not produce sexual spores. In the definitive taxonomy of the genus Aspergillus, Raper \& Fennell (1965) classified some 600 species into 18 groups, one of which is nidulans. The nidulans group includes some 20 ascosporic and nonascosporic species including ascosporic $A$. nidulans. The availability of a probe to the $a c o B$ pre-induction gene allowed us to ask whether homologous sequences exist in other Aspergillus species and, if so, does their presence correlate with some aspect of sporulation. In a Southern blot screening of 16 species, EcoRI-digested DNA was probed with the $1.2 \mathrm{~kb}$ acoB-specific cDNA under high stringency conditions. Although this collection is not a random sample, the results summarized in Table 1 suggest that homology to $a c o B$ is largely restricted to sexually sporulating species that belong to the nidulans group. It should prove interesting to extend this analysis to other species and to other sporulation genes, especially preinduction genes.

\section{ACKNOWLEDGEMENTS}

This research was supported in part by Public Health Service Grant GM 17020 and the Charles and Johanna Busch Memorial Fund. We would like to thank Amy W. Chang for expert technical assistance.

\section{REFERENCES}

Adams, T. H., Hide, W. A., Yager, L. N. \& Lee, B. N. (1992). Isolation of a gene required for programmed initiation of development by Aspergillus nidulans. Mol Cell Biol 12, 3827-3833.

Axelrod, D. E., Gealt, M. \& Pastushok, M. (1973). Gene control of developmental competence in Aspergillus nidulans. Dev Biol 34, 9-15.

Ballance, D. J., Buxton, F. P. \& Turner, G. (1983). Transformation of Aspergillus nidulans by the orotidine- 5 '-phosphate decarboxylase gene of Neurospora crassa. Biochem Biophys Res Commun 112, 284-289.

Butnick, N. Z., Yager, L. N., Hermann, T. E., Kurtz, M. B. \& Champe, S. P. (1984a). Mutants of Aspergillus nidulans blocked at an early stage of sporulation secrete an unusual metabolite. $J$ Bacteriol 160, 533-540.

Butnick. N. Z., Yager, L. N., Kurtz, M. B. \& Champe, S. P. (1984b). Genetic analysis of mutants of Aspergillus nidulans blocked at an early stage of sporulation. $J$ Bacteriol 160, 541-545.

Champe, S. P., Rao, P. \& Chang, A. (1987). An endogenous inducer of sexual development in Aspergillus nidulans. $J$ Gen Microbiol 133, 1383-1387.

Dean, R. A. \& Timberlake, W. E. (1989). Regulation of the Aspergillus nidulans pectate lyase gene (pelA). Plant Cell 1, 275-284.

Jurgenson, J. E. \& Champe, S. P. (1990). The sexual and asexual spores of Aspergillus nidulans contain partially overlapping sets of mRNAs. Exp Mycol 14, 89-93.

Kurtz, M. B. \& Champe, S. P. (1981). Dominant spore color mutants of Aspergillus nidulans defective in germination and sexual development. J Bacteriol 148, 629-638.

May, G. S., Gambino, J., Weatherbee, J. A. \& Morris, N. R. (1985). Identification and functional analysis of beta-tubulin genes by site specific integrative transformation in Aspergillus nidulans. J Cell Biol 101, 712-719.

Miller, B. L., Miller, K. Y. \& Timberlake, W. E. (1985). Direct and indirect gene replacements in Aspergillus nidulans. Mol Cell Biol 5, 1714-1721.

Osmani, S. A., May, G. S. \& Morris, N. R. (1987). Regulation of the mRNA levels of nim $A$, a gene required for the G2-M transition in Aspergillus nidulans. J Cell Biol 104, 1495-1504.

Pontecorvo, G., Roper, J. A., Hemmons, L. M., MacDonald, K. D. \& Buffon, A. W. J. (1953). The genetics of Aspergillus nidulans. Adv Genet 5, 141-238. 
Prade, R. A. \& Timberlake, W. E. (1993). The Aspergillus nidulans brl $A$ locus consists of overlapping transcription units that are individually required for conidiophore development. EMBO J 12, 2439-2447.

Raper, K. B. \& Fennell, D. I. (1965). The Genus Aspergillus. Baltimore: Williams \& Wilkins.

Timberlake, W. E. (1980). Developmental gene regulation in Aspergillus nidulans. Dev Biol 78, 497-510

Timberlake, W. E. (1986). Isolation of stage- and cell-specific genes from fungi. In Biology and Molecular Biology of Plant-Pathogen Interactions, NATO ASI Series, Vol. H1, pp. 343-357. Edited by J. Bailey. Berlin: Springer-Verlag.

Timberlake, W. E. (1990). Molecular genetics of Aspergillus development. Annu Rev Genet 24, 5-36.

Timberlake, W. E., Boylan, M. T., Cooley, M. B., Mirabito, P. M., O'Hara, E. B. \& Willett, C. E. (1985). Rapid identification of mutation-complementing restriction fragments from Aspergillus nidulans cosmids. Exp Mycol 9, 351-355.

Waring, R. B., May, G. S. \& Morris, N. R. (1989). Characterization of an inducible expression system in Aspergillus nidulans using alc $A$ and tubulin-coding genes. Gene 79, 119-130.

Welch, M. D., Vinh, D. B. N., Okamura, H. H. \& Drubin, D. G. (1993). Screens for extragenic mutations that fail to complement act1 alleles identify genes that are important for actin function in Saccharomyces cerevisiae. Genetics 135, 265-274.

Yager, L. N., Kurtz, M. B. \& Champe, S. P. (1982). Temperatureshift analysis of conidial development in Aspergillus nidulans. Dev Biol 93, 92-103.

Received 30 December 1994; revised 29 March 1995; accepted 25 April 1995. 